\section{MR. W. W. RUNIIELI.}

A

LARGE circle connected with the British Mercantile Marine, besides many others interested in magnetic science, will regret to learn that $W . W$. Rundell, so long associated with Liverpool and its nattical affairs, died a few weeks ago at the advanced age of eighty-one.

IVe first hear of Rundell in 1845 , when he became Secretary of the Cornwall Polytechnic Society, a post which he held until 1855 , when he was appointed Secretary of the Liverpool Compass Committee.

It will be remembered that this Committee sat during the years $1855^{-57}$, and by 1860 had made three reports to the Board of 'Trade on the magnetism of a majority of the iron ships leaving the port of Liverpool, the necessary compensations to be made for the resulting deviations of ship's compasses, and the proper equipment and placing of such compasses. This was a work of the highest importance at a time when iron ships were rapidly increasing in numbers, and much danger existed in their navigation from the ignorance which prevailed on the subject.

To Rundell was entrusted the details of the experimental investigations, and the keeping the necessary records of proceedings, an onerous post which he occupied with great zeal and marked perception in reducing and coordinating a mass of results, often of an apparently contradictory nature.

In the spring of 1857 the Liverpool Compass Committee was dissolved, and Rundell was appointed Secretary of the Underwriters' Association of Liverpool ; but for the succeeding three and a half years he worked during his leisure hours at the preparation of the valuable third Report of the Liverpool Compass Committee, and this altogether as an honorary task.

A though in many questions relating to the magnetism of ships he was ready to work cordially with Smith and Evans, who were then carrying on an important work connected with the magnetism of ships in the Royal Navy, Rundell had one important difference of opinion with them-as regards the mechanical correction of compasses.

Smith and Evans objected strongly to compensating the standard compasses of ships by magnets and soft iron, advocating reliance upon deviation tables for correcting the compass courses steered. Rundell, supported by his friend Towson, insisted on the complete compensation of compass errors, so strongly advocated by Airy the inventor of the methods of doing so. The Mercantile Nary followed him, and he has lived to see the Royal Navy more bent on rigorous compensation than the Mercantile.

In 1862 he contributed an excellent paper on compass equipment in iron ships to the Institution of Naval Architects, followed by another on the same subject in I 866. This latter paper contained a vigorous protest against Government supervision of merchant vessels as regards their compasses, and especially to placing the regulation of their equipment under the control of the Admiralty Compass Department, as proposed by the Royal Society to the Board of Trade, but declined by the Board.

Rundell, however, did not content himself with a protest, but made some excellent propositions, which for the most part have been adopted by the Board of Trade.

Zealous and painstaking in whatever he undertook, firm in any position which his well-balanced mind caused him to take up, Rundell was of a kindly disposition and surrounded by friends, many of whom he has survived. $\mathrm{He}$ has left an indelible mark on the service to the benefit of which so many years of his life were devoted.

NO. [43I, VOL. 55]

\section{NOTES}

ON Monday last, Lord Lister's professional brethren gave a visible sign of their high regard for him, and their appreciation of his work, by presenting his portrait, executed by Mr. W. W. Ouless, R.A., to the Royal College of Surgeons. In making the presentation on behalf of the subscribers, Mr. Davies Colley remarked that before long he hoped that those thousands who owed life and health to Lord Lister's discoveries would show their gratitude by founding some institution, or raising some great monument in his honour. There was, however, a special fitness in having a portrait painted of one who had done so much to advance the science of surgery, and placing the picture side by side with the portraits of John Hunter, Astley Cooper, and the other great surgeons who had done similar work. Sir William MacCormac, President of the College, in accepting the portrait, pointed out that a revelation in surgery, one of the most beneficent which has happened in our time, has been the result of Lister's patient investigation. It was not necessary to enter into details as to the incalculable benefit which has flowed from the application of antiseptic principles to surgery. Every surgeon must feel a debt of personal gratitucle to the man who enabled operations in surgery to be practised with a safety and in a manner heretofore unknown. In the course of a brief reply, Lord Lister is reported by the Times to have said: "It would be affectation to deny that I feel this occasion to be one of extreme gratification. I cannot but be conscious that it is a very high personal honour and a remarkable token of esteem and kindly feeling on the part of my colleagues in the noble profession of surgery. But I confess I feel it still more gratifying as a remarkable indication of the general acceptance of the principles which I have for so long a time striven to establish and to promulgate. I am glad this meeting cammot be regarded in any sense as a mere meeting of congratulation on the distinction, great as I am bound to say I feel it to be, which it has pleased Her Majesty to confer upon me, because this project of a portrait was set going before that honour was thought of. This circumstance makes the occasion still more markedly a tribute to the truth and importance of antiseptic principles. Those principles are now more and more recognised throughout our profession, and with increasing benefit to mankind. I was reading only to-day a pamphlet which was sent to me by the author, Dr. Coaley, of New York. In it it was stated that in 360 antiseptic operations for the radical cure of hernia, only one death occurred, not caused apparently by the operation, but by the anzsthetic ether given to a child with weak lungs. An achievement like that is enough to cause glad. ness in the heart of any man who loves his fellow-men. And yet I cannot help remarking that such results could not have been obtained by the mere recognition of the truth or importance of antiseptic principles. Such success implied that the operator was not only convinced of the truth of those principies, but also that he vigilantly maintained throughout his operations that earnest care which is necessary to prevent those principles from being contravened."

Prof. Hermanx MuNk has been elected president of the Berlin Physiological Society, in succession to the late Prof. Du Bois Reymond.

THE Swedish Academy of Agriculture of Stockholm has awarded its gold medal to Prof. J. Eriksson, for his researches on the rust of cereals.

A commitres has been formed to collect international subscriptions for the erection of a memorial to the late Prof. Galileo Ferraris in the Royal Industrial Museum, Turin. 